\title{
Targeted Therapy and Its Availability in Serbia
}

\author{
Aleksandra M. Kovačević1 ${ }^{1}$ Nemanja K. Rančić ${ }^{1}$, Dino K. Tarabar ${ }^{2}$, \\ Viktorija M. Dragojević-Simić ${ }^{1}$ \\ ${ }^{1}$ Centre for Clinical Pharmacology, Medical Faculty, Military Medical Academy, \\ University of Defense, Belgrade, Serbia; \\ ${ }^{2}$ Clinic of Gastroenterology, Medical Faculty, Military Medical Academy, \\ University of Defense, Belgrade, Serbia
}

\section{SUMMARY}

Targeted therapy has made a significant breakthrough for the treatment of different kind of severe diseases, mostly oncological and autoimmune ones. Biological or biotech products, as well as small synthetic molecules, like family of tyrosine kinase inhibitors, have already expressed their efficacy in several important indications. Their availability on the market and reimbursement possibility is of great importance, especially for the patients needed to be on lifelong therapies. Targeted therapy enhanced progression free and overall survival in many conditions, but also a number of these therapies produced important and severe side effects. Considering the fact that targeted therapy is on the global market relatively shortly, there is necessity for prolonged therapy monitoring: for further effectiveness assessment, for safety profile and long term health consequences establishment. Reimbursed targeted therapy proved its benefits that overweight risks, but still remains extremely high costs problem for its application. For an upper middle income country like Serbia, with significantly lower health care expenditures per capita than in other well developed countries, the availability of this expensive therapy is not yet gratifying.

Keywords: targeted therapy; biological; costs; reimbursement; Serbia

\section{INTRODUCTION}

Targeted therapy made a significant breakthrough for the treatment of different kind of severe diseases, like malignancies, neurological diseases, hepatitis, anemia and other kinds of autoimmune ones. Comparing to the conventional therapy, it offers advantages in cell-specific mechanism of action. Its acute toxicity profile differs from cytotoxic therapy and shows stunning improvement in patient survival and disease remission. However, taking into consideration that many modified cellular signaling pathways are of substantive importance for growth or homeostasis of normal cells, there is still not enough clinical experience for prolonged period of utilization and of long term toxicity profile of these drugs [1]. Drugs for targeted therapy are mostly biological or biotech products, but there are also small synthetic molecules, like family of tyrosine kinase inhibitors, that expressed their efficacy in several indications. Their availability on the market and reimbursement are of great importance, especially for patients needed to be on lifelong therapies. 


\section{EXPENDITURE FOR HEALTH CARE AND PHARMACEUTICALS}

Spending for health care and pharmaceuticals are useful indicators for obtaining picture of overall drugs funds and therefore their availability. In European Union (EU) countries, expenditure for health care was rising until 2010 and reached more than $9 \%$ of Gross Domestic Product (GDP), in average. Slowdown in growth of healthcare spending in 2010 occurred, but still achieving 9\% of GDP [2]. Health expenditure per capita in Serbia, for year 2011, was 622 USD (or 479 EUR) and 10\% of GDP [3], which was, as expected, much less than in, e.g. Norway and Switzerland, two European countries with largest spending per person (more than 4,000 EUR) [2].

Spending on pharmaceuticals is the third biggest component (with 19\%) of all healthcare expenditure, on average, in EU member states. In Serbia, 279 EUR per capita was spent on prescription drugs and OTC in 2010, which was a more than $30 \%$ of total health expenditure. For hospital setting, hospital medicines cost $15 \%$ of all expenses for prescription and self-medication drugs [2].

In Germany, where annual health care costs 3,300 EUR and pharmaceutical spending of almost 500 EUR per capita [2], biotech drugs accounted for $13 \%$ of all pharmaceutical spending represented with $4 \%$ of prescriptions [4]. Annual therapy cost per patient of most biotech drugs could mount up to 70,000 EUR and for rare genetic diseases more than 200,000 EUR [5]. Therefore, urgent need for costs monitoring and their cutting, on the one hand, and necessity of targeted therapy availability, on the other, has to be balanced.

A worldwide trend is observed that the rate of approved new drug entities slowed down, and a number of biosimilars and "me too" biotech drugs grow up. However, biopharmaceutical sector represents a significant part of pharmaceutical market. In 2007, value of all biologics sales was $16 \%$ of all pharmaceutical market [6].

As expected, a half of the total number of biotech companies is geographically located in US (216), in Europe (134) and the rest other in the world. Ten top selling biologic drugs of 2011, on global market, were: adalimumab, etanercept, rituximab, infliximab, bevacizumab, trastuzumab, pegfilgrastim, ranibizumab, interferon beta 1-a and interferon beta 1-b [7]. It is obvious that $60 \%$ of them are monoclonal antibodies (mAbs). Monoclonal antibodies accounted for almost half of all biopharmaceutics' sales in 2010, which mounted up to USA $\$ 108$ billion [8].

\section{REIMBURSED BIOLOGICAL DRUGS IN SERBIA}

Biological medicinal products are recognized by Serbian low on medical products and medical devices [9], including immunological drugs (vaccines, serums, allergenic extracts), blood and blood products, gene therapy products and bioengineered drugs obtained from tissue and cellular cultures. Many of them are available to patients under national health insurance coverage and are included in the national List of medicines [10]. Biological medicinal products, as well as other targeted therapy drugs, as a part of different ATC groups of drugs, are listed among the ones used mostly in hospital settings and with specific routs of administration. The most expensive drugs, with specific rules of prescribing, such as monoclonal antibodies, erythropoietins, proteasome inhibitors, interferons, etc. are ranked in special part of national drug list (so called "List C"). They could be obtained for certain indications and under specific conditions, for each of these drugs.

\section{Erythropoietin}

Group of antianemic preparations, for symptomatic anemia treatment in patients with chronic kidney failure, is represented by erythropoietin alfa, beta and zeta, darbepoetin alfa and methoxy polyethylene glycol-epoetin beta in the Serbian List of medicines [10].

Erythropoietin is a glycoprotein that stimulates the formation of erythrocytes from precursors of the stem cell compartment. The protein fraction of the molecule consists of 165 amino acids. Epoetin alfa obtained by gene technology is glycosylated and identical in its amino acid and carbohydrate composition to endogenous human erythropoietin [11]. Erythropoietin is the principal regulator of the process of erythropoiesis, which maintains an optimal circulating red cell mass for oxygen delivery to the tissues [12]. It binds to and activates specific receptors on red cell progenitors in the bone marrow. Signal transduction via the erythropoietin receptor prevents apoptosis of erythroid 
cells, permitting their further proliferation and differentiation into mature erythrocytes [13]. The subsequent increase in red cell mass occurs and improves tissue oxygenation [14].

Biosimilar erythropoietins are among first biosimilar drugs available on the global market, since 2007, when patent protection expired for the original epoietin alpha $\left(\right.$ Eprex $\left.^{\otimes}\right)$ [15]. For demonstration of similar efficacy of biosimilar epoetin and the originator, if change from baseline in hemoglobin is used, as the primary endpoint, European Medicines Agency (EMA) considers acceptance range of $\pm 0.5 \mathrm{~g} / \mathrm{dL}$ in blood hemoglobin concentrations, within $95 \%$ confidence interval. In terms of clinical safety, the use of a validated, highly sensitive antibody assay is mandatory, able to detect both early (low affinity antibodies) and late (high affinity antibodies) immune responses [16].

In research studies, it is shown that the quality of biosimilar epoetins is high, and the various epoetin products have major differences in potency and possible impact on immunogenicity toward their isoform composition [17]. Main impediments in erythropoietins usage remain their immunogenicity (formation of neutralizing antibodies), costs and parenteral administration [14].

\section{Rituximab}

Rituximab is a chimeric $\mathrm{mAb}$, reimbursed by Serbian National Health Insurance Fund (NHIF) for following indications: non-Hodgkin's lymphoma (NHL) and rheumatoid arthritis (RA) [10]. It is the first $\mathrm{mAb}$ approved in US for cancer treatment, and later for RA, in combination with methotrexate. Theoretically, rituximab could be used for treatment of every disease in which $B$ lymphocytes play an essential role. B cells are antibody producing and antigen presenting cells, thus in theory most auto-immune diseases could be treated and benefit from rituximab [18].

The Fab domain of rituximab binds to the transmembrane antigen $\mathrm{CD} 20$ on B lymphocytes and the $\mathrm{Fc}$ domain can recruit immune effectors functions to mediate B cell lyses. CD20 is expressed on more than $95 \%$ of all B cell non-Hodgkin's lymphomas [19].

$B$ cells are probably playing a role in the pathogenesis of RA and associated chronic synovitis. The B cells may be acting at multiple sites in the autoimmune/inflammatory process, including through production of rheumatoid factor (RF) and other autoantibodies, antigen presentation, T-cell activation and/or proinflammatory cytokine production [20]. In addition of the approved indications for rituximab, there are many clinical trials conducting, in order to confirm, where applicable, off-label use of difficult-to-treat autoimmune diseases [18]. However, there have to exist activities for the pharmacovigilance and interventions detailed in the agreed Risk Management Plan presented in the official documents and obligations by law. Hypersensitivity to the active substance and active, severe infections remain main contraindications for therapy with this $m A b$ [19]. There are still no registered biosimilars of rituximab in the global market.

\section{Trastuzumab}

Among breast cancers diagnosed at any stage, $20-30 \%$ are found to have amplification of the human epidermal growth factor receptor (HER2) and consequently over expression of a trans membrane protein with tyrosine kinase activity [21]. Trastuzumab (Herceptin ${ }^{\circ}$ ) is a recombinant humaniszed IgG1 mAb, indicated for the treatment of patients with HER2 positive metastatic breast cancer as monotherapy or in combination with other chemotherapeutics; it is reimbursed by NHIF for this indication. Aditionally, it is indicated for the treatment of patients with metastatic gastric cancer whose tumors have HER2 over expression. It was first approved by the FDA, in 1998. Trastuzumab binds with high affinity and specificity to HER2 extracellular domain, inhibits ligand-independent HER2 signaling and prevents an activation mechanism of HER2. As a result, inhibition of the proliferation of human tumor cells that over express HER2 occurs [22]. The main problem of trastuzumab therapy remains heart failure that has been observed in patients receiving Herceptin therapy alone or in combination with paclitaxel or docetaxel, particularly following anthracycline-containing chemotherapy. Therefore, all potential patients for treatment with trastuzumab, but especially those with prior anthracycline and cyclophosphamide exposure, should undergo baseline cardiac assessment and a careful risk-benefit assessment should be made before deciding to treat with trastuzumab [23]. At last, significantly high annual costs for trastuzumab treatment 
which could reach up to 70,000 USD, should be taken into consideration [24].

\section{Cetuximab}

First approval of cetuximab for the treatment of patients with advanced colorectal cancer was by FDA in 2004. After one year, at the beginning of 2006, indication was expanded, and it was used for the head and neck cancer patients' treatment [25]. There are still no therapeutic equivalents to this biotech drug. Erbitux (cetuximab) is a recombinant, human/mouse chimeric monoclonal antibody that binds specifically to the extracellular domain of the human epidermal growth factor receptor (EGFR). Erbitux is indicated for the treatment of K-Ras mutation-negative (wild-type), epidermal growth factor receptor (EGFR)-expressing, metastatic colorectal cancer (mCRC) [26]. It has been shown to increase overall survival in mCRC by about $4-5$ month in chemotherapy refractory disease [27]. Adverse reactions from this $\mathrm{mAb}$ include common injection reactions, rash, diarrhea, venous thromboembolic events and electrolyte abnormalities. There is no benefit of addition of another $\mathrm{mAb}$ to standard chemotherapy combination [1].

\section{Bevacizumab}

Bevacizumab (Avastin) is recombinant humanized monoclonal IgG1 antibody, indicated for use in combination with other chemotherapeutic agents in metastatic colorectal carcinoma, metastatic breast cancer, non-small cell lung cancer, advanced and/or metastatic renal cell cancer and ovarian cancer [28]. It is $\mathrm{mAb}$ against the ligand of vascular endothelial growth factor receptor (VEGFR). It is believed that VEGFR pathway plays an important role in a many malignant diseases. First approval of bevacizumab was in 2004, by FDA, and indicated for first-line treatment of patients with metastatic carcinoma of the colon or rectum; since 2006 and afterwards, new indications for treatment of non small cell lung cancer, glioblastoma and renal cell carcinoma, were added [29]. First marketing authorization in Europe was in 2006, by EMA. In Serbia, therapy with this $\mathrm{mAb}$ is reimbursed only for metastatic colorectal cancer use. There are still no therapeutic equivalents to this drug on the market. It has already been established that bevacizumab use with irinotecan plus 5-fluorouracil and leucovorin combination increases overall survival in metastatic colon cancer approximately by 4 months [30]. Addition of bevacizumab to adjuvant chemotherapy has not shown any benefit, as well as addition of other mAbs [1]. However, increase in adverse reactions associated with bevacizumab was seen, which included gastrointestinal perforation, arterial thromboembolic events, bleeding events, wound healing complications, hypertension [31].

\section{Imatinib}

Imatinib is one of the families of tyrosine kinase inhibitor molecules, which potently inhibits the Bcr-Abl tyrosine kinase. It selectively inhibits proliferation and induces apoptosis in Bcr-Abl positive cell lines, as well as fresh leukemic cells from Philadelphia chromosome positive chronic myeloid leukemia (CML) and acute lymphoblastic leukemia (ALL) patients. First imatinib licenesed product (Glivec ${ }^{\circ}$ ) in EU was authorized by EMA in 2001, and it is indicated for treatment of CML, ALL, unrespectable and/ or metastatic malignant gastrointestinal stromal tumors (GIST) [32]. Since the introduction of imatinib for treatment of CML, studies have shown that almost $80 \%$ of all treated patients had progression free and overall survival. It is even estimated that majority of patients with CML have normal life expectancy [1]. From the beginning of 2013 new imatinib containing drugs have got marketing authorization in EU (Imatinib Teva ${ }^{\circ}$, Imatinib Actavis $\left.{ }^{\circ}\right)$. There are 2 imatinib products that are reimbursed by NHIF for patients with CML and GIST in Serbia. This drug is orally administered and shows large efficacy in CML, without substantial toxic effects, as shown in has been shown in different clinical studies [33]. Observed common adverse effects are severe fluid retention, infection, unexpected bleeding and some other uncommon or rare side effects [32]. The benefits of treatment with imatinib, accompanied by adverse effects, have to be managed to ease a patient's adherence to this significant therapy.

Gefitinib, erlotinib, sunitinib, lapatinib, nilotinib

A large number of tyrosine kinase inhibitors (TKIs) have been developed and have shown 
success in treating different malignant diseases. Some of them are reimbursed by Serbian NHIF for different indications: non-small cell lung cancer (gefitinib), lung adenocarcinoma (erlotinib), metastatic renal cell carcinoma (sunitinib), breast cancer (lapatinib) and CML (nilotinib) [10]. All TKIs have the same mechanism of action, mostly competitive ATP inhibition at the binding site of tyrosine kinase, but they differ from each other in spectrum of targeted kinases [34].

Erlotinib and gefitinib are targeting mutated active epidermal growth factor receptor (EGFR) and showed approximately 6 month improvement in progression free survival in patients with non-small cell lung cancer compared with conventional chemotherapy [35]. Advantage of TKIs therapy is also their oral route of administration. Main adverse effects are due to exerting their cytotoxic effects. Problem in therapy also begins with cell resistance through mutations in the kinase gene that leads to decreasing of drug binding. TKIs mostly evoke different adverse effects on skin and hair (erlotinib and gefitinib), hemorrhage and edema (sunitinib), hematological side effects and cardiac toxicity [34].

However, benefit in overall survival achieved in the therapy with these drugs overweight mostly side effects. Still, remains need for carefully balanced administration and getting new data of long-term side effects, since the relatively short period of time they have been approved for the treatment [1].

\section{Bortezomib}

An essential role in regulating homeostatic and cellular events involved in cancer genesis plays ubiquity - proteasome pathway. Bortezomib (Velcade ${ }^{\circ}$ is the first proteasome inhibitor approved by FDA in 2003, than in 2004 by EMA, as antineoplastic drug for treatment of multiple myeloma patients $[36,37,38]$. It has demonstrated apoptotic inducing activity in a multiple tumor cell lines. Less encouraging results then in hematological malignances have been obtained using bortezomib in treatment of solid tumors, but, at the moment, it is tested in combination with other conventional chemotherapeutics and radiotherapy in such indications [39]. In patients with regressed multiple myelomas, bortezomib as monotherapy showed significant increase in overall survival period [40]. The most common adverse effects of bor- tezomib treatment are peripheral neuropathy, hypotension, cardiac and pulmonary toxicity, thrombocytopenia and hepatic toxicity [36].

\section{Interferons}

Interferons (IFNs) are integral part of native immune response to pathogen-associated molecular patterns. There are various IFNs subtypes and their immunomodulatory, antiviral and anticarcinogenic properties are researched extensively [41]. For the therapeutic use, several formulations of interferon are on the market in Serbia and reimbursed: interferon beta 1a (Avonex, Rebif), interferon beta $1 \mathrm{~b}$ (Betaferon); conjugated (pegylated) forms of interferons: peginterferon alfa $2 \mathrm{~b}$ (Pegintron) and peginterferon alfa $2 \mathrm{a}$ (Pegasys) [10]. Interferons beta $1 \mathrm{a}$ and $1 \mathrm{~b}$ are used for treatment of patients with multiple sclerosis, a chronic neurological condition that is characterized by neuronal inflammation and demyelization. In spite of possible forming of neutralizing antibodies against IFN beta, long term efficacy has been proven [41, 42]. Pegylated interferons alfa are the standard of care in combination with some other antiviral drugs for chronic hepatitis $\mathrm{B}$ and $\mathrm{C}$ infection. IFNs are not reimbursed by NHIF for use in other indications, as in advanced renal cell carcinoma, even though survival benefit exists when combined with anti-VEGF $\mathrm{mAb}$ - bevacizumab [43].

IFNs could provoke common side effects, like flu-like symptoms, lethargy, autoimmune disease, myelosupression, neutropenia, depression, pneumonitis and pulmonary arterial hypertension [44].

\section{Glatiramer acetat}

Multiple sclerosis (MS) is a chronic, inflammatory disease of CNS, characterized by multifocal demyelization, neuronal and axonal damage followed by sclerotic plaques formation in any part of CNS. Glatiramer acetate is a synthetic analogue of myelin basic protein (MBP), an antigen involved in MS pathogenesis. It blocks MBP from binding to lymphocytes - antigen presenting cells on the periphery and impedes their stimulation [45]. This drug is used in therapy since its first approval by FDA, in 1996. It is indicated for use in ambulatory patients with relapsed remittent multiple sclerosis for reduc- 
tion of relapses, but not in primary or secondary progressive MS. The very common adverse reactions to this drug are infection, influenza, anxiety, headache, vasodilatation, dyspnea, chest pain and injection site reactions [46].

\section{Tumor necrosis factor alpha inhibitors (etanercept, infliximab, adalimumab, golimumab)}

Treatment of rheumatoid arthritis, as a chronic autoimmune inflammatory disease, demands application of conventional disease-modifying antirheumatic drugs (cDMARDs) in a first line treatment. If suboptimal response or intolerance occurs, then biological DMARDs are value alternative [47]. Tumor necrosis factor alpha (TNFa) inhibitors are substantial part of this group of drugs.

Etanercept is a human TNFa receptor fusion protein, produced by recombinant DNA technology. It binds to and neutralizes the biological activity of TNF, therefore preventing TNF mediated signal transduction. It is indicated for treatment of moderate to severe RA in combination with methotrexate or as monotherapy, as well as for juvenile idiopathic arthritis, psoriatic arthritis and ankylosing spondylitis [48]. It is authorized for the first time in Europe in 2006. It showed significantly better results in reduction of disease activity and improvement of functional disability [49].

Infliximab is a chimeric monoclonal antibody that binds with high affinity to TNFa. It is reimbursed for treatment of Crohn's disease, ulcerative colitis, as well as rheumatoid arthritis, psoriatic arthritis and ankylosing spondylitis. A decision analytic model constructed in order to obtain risks and benefits of infliximab in Crohn's disease showed that comparing with standard therapy, infliximab resulted in more quality-adjusted life years (QALYs) per patient [50]. Very common undesirable effects of infliximab were viral and bacterial infections, blood and lymphatic system disorders, abdominal pain and nausea, increased transaminases and infusion related reactions [51]. Rare but serious complications are lymphoma, sepsis and death, but in properly selected patients, benefits overweight risks associated with infliximab administration [50].

Adalimumab is recombinant human $\mathrm{mAb}$ which acts similarly like infliximab, by binding with high affinity to TNFa [52]. This biological
DMARD is reimbursed for the same indications as infliximab, and showed similar efficacy and tolerability, with similar annual costs of therapy [53].

Golimumab is a novel anti-TNFa blocker, full human $\mathrm{mAb}$, acting on both forms of TNFa. It is approved for rheumatic arthritis, psoriatic arthritis and ankylosing spondylitis. Golimumab showed significant improvement in patients with ankylosing spondylitis compared to placebo, as well as in patients with rheumatoid arthritis in combination with methotrexate $v s$. methotrexate alone. The main adverse effects with this drug are infections, abnormal liver function, hypertension and some cases of malignancies [54].

\section{Tocilizumab}

Tocilizumab is indicated for treatment of RA in patients with no adequate response with conventional or biological DMARDs. Its mechanism of action differs from other bDMARDs, since it is recombinant monoclonal IgG1 anti-human IL-6 receptor (IL-6R) antibody [55]. Tocilizumab showed superiority in many clinical studies comparing to methotrexate therapy, and it showed response in patients who failed to respond to anti-TNF blockers therapy [56]. Its safety is favorable for both short-term and long-term treatment. Adverse effects were less severe compared to other biologic therapies, predominantly infections occurred [55].

\section{FUTURE DIRECTION AND CONCLUSIONS}

There is no doubt that targeted therapy made a significant step forward in treatment of different, life-threatening and long-lasting diseases. It enhanced progression free and overall survival in many conditions, but also a number of these therapies produced important and severe side effects. Some of them could be tolerated for a short time period, but for lifelong therapies, it is difficult to obtain acceptable patients' quality of life or even avoid life threatening conditions. Considering the fact that targeted therapy is on the global market relatively briefly, there is necessity for prolonged therapy monitoring: for further effectiveness assessment, for safety profile as well as for long term health consequences establishment. Reimbursed targeted 
therapy proved its benefits that overweight risks, but still remains extremely high costs problem for its application. For an upper middle income country like Serbia, with significantly lower health care expenditures per capita than in well developed countries, the availability of this expensive therapy is not yet gratifying.

\section{ACKNOWLEDGMENTS}

The authors of this paper would like to express their gratitude to the Ministry of Education, Science and Technological Development of the Republic of Serbia for Grant $N^{\circ} 175014$.

\section{Conflict of Interest Statement}

The authors certify that there are no potential conflicts of interest.

\section{REFERENCES}

1. Palumbo MO, Kavan P, Miller WH Jr, Panasci L, Assouline S, Johnson N, et al. Systemic cancer therapy: achievements and challenges that lie ahead. Front Pharmacol. 2013; 4:57.

2. OECD [Internet]. Health at a Glance: Europe 2012. European Union: OECD; 2012 [cited 2013 June 15]. Available from: http://dx.doi. org/10.1787/9789264183896-en.

3. The World Bank group [Internet]. Health expenditure per capita. The World Bank [updated 2013; cited 2013 June 17]. Available from: http://data. worldbank.org/indicator/SH.XPD.PCAP/ countries.

4. Biotechnologie.de [Internet]. Biotech drugs raise costs, say critics. Germany: biotechnologie.de c/o BIOCOM [cited 2013 June 17]. Available from: http://www.biotechnologie.de/BIO/Navigation/ $\mathrm{EN} /$ root,did=96830.html?listBlld=74464\&.

5. Fojo T, Grady C. How much is life worth: cetuximab, non-small cell lung cancer, and the $\$ 440$ billion question. J Natl Cancer Inst. 2009; 101:1044-8.

6. Walsh G. Biopharmaceutical benchmarks 2010. Nat Biotechnol. 2010; 28(9):917-24.

7. Huggett B, Lahteenmaki R. Public biotech 2011 the numbers. Nat Biotechnol. 2012; 30(8):751-7.

8. Dimitrov DS. Therapeutic proteins. Methods Mol Biol. 2012; 899:1-26.

9. Official Gazette of the Republic of Serbia [Internet]. Law on medicinal products and medical devices. Serbia: Official Gazette of the Republic of Serbia no. 30/2010; 2010 [cited 2013 June 17]. Available from: http://www.alims. gov.rs/eng/files/2013/04/Law-on-Medicinesand-Medical-Devices-2010.pdf.

10. Republic Fond of Health Insurance [Internet]. List of medicines. Serbia: Republic Fond of Health Insurance [updated 2009; cited 2013 June 17]. Available from: http://www.eng.rfzo.rs/index. php/list-of-medicines.
11. Datapharm Communications Ltd [Internet]. Eprex, Summary of Product Characteristics. JannsenCilag Ltd [updated 2012; cited 2013 June 17]. Available from: http://www.medicines.org.uk/ emc/medicine/889/spc.

12. Erslev AJ. Erythropoietin. N Engl J Med. 1991; 324(19):1339-44.

13. Koury MJ, Bondurant MC. Erythropoietin retards DNA breakdown and prevents programmed death in erythroid progenitor cells. Science. 1990; 248(4953):378-81.

14. Maxwell AP. Novel erythropoiesis-stimulating protein in the management of the anemia of chronic renal failure. Kidney Int. 2002; 62(2): 720-9.

15. Weise M, Bielsky MC, De Smet K, Ehmann F, Ekman N, Giezen TJ, et al. Biosimilars: what clinicians should know. Blood. 2012; 120(26):5111-7.

16. European Medicines Agency [Internet]. Guideline on non-clinical and clinical development of similar biological medicinal products containing recombinant erythropoietins (Revision). London: European Medicines Agency, Committee for Medicinal Products for Human Use, 2010 [cited 2013 June 17]. Available from: http://www.ema.europa.eu/ docs/en_GB/document_library/Scientific_guideline/2010/04/WC500089474.pdf.

17. Brinks V, Hawe A, Basmeleh A, Joachin-Rodriguez L, Haselberg R, Somsen GW, et al. Quality of Original and Biosimilar Epoetin Products. Pharm Res. 2011; 28(2):386-93.

18. Sailler L. Rituximab off label use for difficult-to-treat auto-immune diseases: reappraisal of benefits and risks. Clin Rev Allergy Immunol. 2008; 34:103-10.

19. European Medicines Agency [Internet]. MabThera Summary of product characteristics. London: European Medicines Agency [cited 2013 June 10]. Available from: http://www.ema.europa.eu/ docs/en_GB/document_library/EPAR-Product_ Information/human/000165/WC500025821.pdf.

20. Genentech, Inc [Internet]. Rituxan, Full prescribing information. South San Francisco: Biogen Idec, Inc. and Genentech, Inc [cited 2013 June 10]. Available from: http://www.gene.com/ download/pdf/rituxan_prescribing.pdf.

21. Dahabreh IJ, Linardou H, Siannis F, Fountzilas G, Murray S. Trastuzumab in the adjuvant treatment of early-stage breast cancer: a systematic review and meta-analysis of randomized controlled trials. Oncologist. 2008; 13(6):620-30.

22. Datapharm Communications Ltd [Internet]. Herceptin, Summary of Product Characteristics. Roche Products Limited [updated 2013; cited 2013 June 10]. Available from: http://www. medicines.org.uk/emc/medicine/3567.

23. Seidman A, Hudis C, Pierri MK, Shak S, Paton V, Ashby M, et al. Cardiac dysfunction in the trastuzumab clinical trials experience. J Clin Oncol. 2002; 20(5):1215-21.

24. Fleckr L. The costs of caring: Who pays? Who profits? Who panders? Hastings Cent Rep. 2006; 36(3):13-7.

25. ImClone Systems Incorporated [Internet]. Erbitux. ImClone Systems Incorporated and Bristol-Myers Squibb Company [cited 2013 June 10]. Available from: http://www.accessdata.fda.gov/drugsatfda_docs/label/2004/125084lbl.pdf.

26. ImClone LLC [Internet]. Erbitux, Full prescribing information. ImClone LLC a wholly-owned subsidiary of Eli Lilly and Company, and 
Bristol-Myers Squibb Company [cited 2013 June 8]. Available from: http://www.accessdata.fda. gov/drugsatfda_docs/ label/2013/125084s242lbl.pdf.

27. Karapetis CS, Khambata-Ford S, Jonker DJ, O'Callaghan CJ, Tu D, Tebbutt NC, et al. K-ras mutations and benefit from cetuximab in advanced colorectal cancer. N Engl J Med. 2008; 359(17):1757-65.

28. Genentech, Inc [Internet]. Avastin, Full prescribing information. South San Francisco: Genentech, Inc., A Member of the Roche Group [cited 2013 June 8]. Available from: http://www.gene.com/ download/pdf/avastin_prescribing.pdf.

29. U.S. Department of Health and Human Services [Internet]. Approval History, Letters, Reviews, and Related Documents, Avastin. U.S. Food and Drug Administration [cited 2013 June 8]. Available from: http://www.accessdata.fda.gov/scripts/ cder/drugsatfda/index.cfm?fuseaction=Search. DrugDetails.

30. Hurwitz H, Fehrenbacher L, Novotny W, Cartwright T, Hainsworth J, Heim W, et al. Bevacizumab plus irinotecan, fluorouracil, and leucovorin for metastatic colorectal cancer. N Engl J Med. 2004; 350(23):2335-42.

31. Kozloff M, Yood MU, Berlin J, Flynn PJ, Kabbinavar FF, Purdie DM, et al. Clinical outcomes associated with bevacizumab-containing treatment of metastatic colorectal cancer: the BRiTE observational cohort study. Oncologist. 2009; 14(9):86270.

32. European Medicines Agency [Internet]. Summary of product characteristics, Glivec. London: European Medicines Agency [cited 2013 June 7]. Available from: http://www.ema.europa.eu/ docs/en_GB/document_library/EPAR_-Product Information/human/000406/WC500022207.pdf.

33. Strebhardt K, Ullrich A. Another look at imatinib mesylate. N Engl J Med. 2006; 355(23):2481-2.

34. Hartmann JT, Haap M, Kopp HG, Lipp HP. Tyrosine kinase inhibitors - a review on pharmacology, metabolism and side effects. Curr Drug Metab. 2009; 10(5):470-81.

35. Rosell R, Carcereny E, Gervais R, Vergnenegre A, Massuti B, Felip E, et al; Spanish Lung Cancer Group in collaboration with Groupe Français de Pneumo-Cancérologie and Associazione Italiana Oncologia Toracica. Erlotinib versus standard chemotherapy as first-line treatment for European patients with advanced EGFR mutation-positive non-small-cell lung cancer (EURTAC): a multicentre, open-label, randomised phase 3 trial. Lancet Oncol. 2012; 13(3):239-46.

36. U.S. Department of Health and Human Services [Internet]. Bortezomib, FDA, Label and Approval History. U.S. Food and Drug Administration [cited 2013 June 8]. Available from: http://www. accessdata.fda.gov/scripts/cder/drugsatfda/ index.cfm?fuseaction=Search.Label_ ApprovalHistory\#apphist.

37. European Medicines Agency [Internet]. EMA Product information, Velcade. London: European Medicines Agency [cited 2013 June 7]. Available from: http://www.emea.europa.eu/ema/index. jsp?curl=pages/medicines/human/medicines/000539/human_med_001130.jsp.

38. Chen D, Frezza M, Schmitt S, Kanwar J, Dou QP. Bortezomib as the first proteasome inhibitor anticancer drug: current status and future perspectives. Curr Cancer Drug Targets. 2011; 11(3):239-53.
39. Edelman MJ. The potential role of bortezomib in combination with chemotherapy and radiation in non-small-cell lung cancer. Clin. Lung Cancer. 2005; 7(Suppl 2):S64-6.

40. Richardson PG, Sonneveld P, Schuster MW, Irwin $D$, Stadtmauer EA, Facon T, et al. Assessment of Proteasome Inhibition for Extending Remissions (APEX) Investigators. Bortezomib or high-dose dexamethasone for relapsed multiple myeloma. N Engl J Med. 2005; 352(24):2487-98.

41. George PM, Badiger R, Alazawi W, Foster GR, Mitchell JA. Pharmacology and therapeutic potential of interferons. Pharmacol Ther. 2012; 135(1):44-53.

42. Ebers GC, Traboulsee A, Li D, Langdon D, Reder AT, Goodin DS, et al. Analysis of clinical outcomes according to original treatment groups 16 years after the pivotal IFNB-1b trial. J Neurol Neurosurg Psychiatry. 2010; 81(8):907-12.

43. Escudier B, Pluzanska A, Koralewski P, Ravaud A, Bracarda S, Szczylik C, et al. Bevacizumab plus interferon alfa-2a for treatment of metastatic renal cell carcinoma: a randomised, double-blind phase III trial. Lancet. 2007; 370(9605):2103-11.

44. European Medicines Agency [Internet]. Pegasys, Summary of product characteristics. London: European Medicines Agency [cited 2013 June 1]. Available from: http://www.ema.europa.eu/ docs/en_GB/document_library/EPAR_Product_ Information/human/000395/WC500039195.pdf.

45. Carter NJ, Keating GM. Glatiramer acetate: a review of its use in relapsing-remitting multiple sclerosis and in delaying the onset of clinically definite multiple sclerosis. Drugs. 2010; 70(12):1545-77.

46. Datapharm Communications Ltd [Internet]. Summary of product characteristics, Copaxone. UK: Teva Pharmaceuticals Ltd [cited 2013 June 5]. Available from: http://www.medicines.org.uk/ emc/medicine/17516/SPC.

47. Orme ME, Macgilchrist KS, Mitchell S, Spurden D, Bird A. Systematic review and network meta-analysis of combination and monotherapy treatments in disease-modifying antirheumatic drug-experienced patients with rheumatoid arthritis: analysis of American College of Rheumatology criteria scores 20, 50 and 70. Biologics. 2012; 6:429-64.

48. European Medicines Agency [Internet]. Etanercept, Summary of Product Characteristics. London: European Medicines Agency [cited 2013 June 3]. Available from: http://www.ema.europa. eu/docs/en_GB/document_library/EPAR_-Product Information/human/000262/ WC500027361.pdf.

49. Klareskog L, van der Heijde D, de Jager JP, Gough A, Kalden J, Malaise M, et al. TEMPO (Trial of Etanercept and Methotrexate with Radiographic Patient Outcomes) study investigators. Therapeutic effect of the combination of etanercept and methotrexate compared with each treatment alone in patients with rheumatoid arthritis: double-blind randomised controlled trial. Lancet. 2004; 363(9410):675-81.

50. Siegel CA, Hur C, Korzenik JR, Gazelle GS, Sands $B E$. Risks and benefits of infliximab for the treatment of Crohn's disease. Clin Gastroenterol Hepatol. 2006; 4(8):1017-24.

51. European Medicines Agency [Internet]. Remicade, Summary of Product Characteristics. London: European Medicines Agency [cited 2013 June 3]. Available from: http://www.ema.europa.eu/ docs/en_GB/document_library/EPAR__Product Information/human/000240/WC500050888.pdf. 
52. European Medicines Agency [Internet]. Humira, Summary of Product Characteristics. London: European Medicines Agency [cited 2013 June 3]. Available from: http://www.ema.europa.eu/ docs/en_GB/document_library/EPAR_Scientific_Discussion/human/000481/ WC500050867.pdf.

53. National Institute for Health and Clinical Excellence [Internet]. Adalimumab, etanercept and infliximab for the treatment of rheumatoid arthritis. National Institute for Health and Clinical Excellence: NICE technology appraisal guidance; 2007 [cited 2013 June 10]. Available from: http://www.nice.org.uk/nicemedia/pdf/ ta130guidance.pdf.
54. Rosman Z, Shoenfeld Y, Zandman-Goddard G. Biologic therapy for autoimmune diseases: an update. BMC Med. 2013; 11:88.

55. Donahue KE, Jonas DE, Hansen RA, Roubey R, Jonas B, Lux LJ, et al. Drug Therapy for Rheumatoid Arthritis in Adults: An Update [Internet]. Rockville (MD): Agency for Healthcare Research and Quality (US); 2012 [cited 2013 June 10]. Available from: http://www.ncbi.nlm.nih. gov/books/NBK97388/.

56. Tak PP, Kalden JR. Advances in rheumatology: new targeted therapeutics. Arthritis Res Ther. 2011; 13(Suppl 1):S5.

\title{
Lekovi za ciljanu terapiju i njihova dostupnost u Srbiji
}

\author{
Aleksandra M. Kovačević ${ }^{1}$, Nemanja K. Rančić1, Dino K. Tarabar², \\ Viktorija M. Dragojević-Simić ${ }^{1}$ \\ ${ }^{1}$ Centar za kliničku farmakologiju, Medicinski fakultet, Vojnomedicinska akademija, Univerzitet odbrane, \\ Beograd, Srbija; \\ ${ }^{2}$ Klinika za gastroenterologiju, Medicinski fakultet, Vojnomedicinska akademija, Univerzitet odbrane, \\ Beograd, Srbija;
}

\section{KRATAK SADRŽAJ}

Ciljana (molekulska) terapija je značajno napredovala, naročito u lečenju najtežih, pretežno onkoloških i autoimunskih bolesti. Mnogi biološki ili biotehnološki proizvodi, kao i mali molekuli, kao što su inhibitori tirozin-kinaza, dokazali su svoju efektivnost u nekim važnim indikacijama. Zbog toga je vrlo značajna njihova dostupnost na tržištu i mogućnost refundiranja, naročito za bolesnike koji bi trebalo da doživotno primaju ovu terapiju. Ciljana terapija povećava dužinu i ukupno preživljavanje u mnogim stanjima, ali mnogi ovi lekovi izazivaju i teške neželjene reakcije. Uzimajući u obzir činjenicu da je ciljana terapija na svetskom tržištu relativno kratak vremenski interval, potreban je nadzor nad primenom ovih lekova tokom dužeg perioda, prvenstveno da bi se utvrdili njihova dalja delotvornost, sigurnosni profil i dugoročne posledice po zdravlje bolesnika. Lekovi za ciljanu terapiju koji se refundiraju dokazali su da njihovom upotrebom korist prevazilazi rizike. Međutim, i dalje ostaje problem izuzetno visokih troškova njihovog korišćenja. U Srbiji, koja se ubraja u srednje razvijene zemlje na osnovu bruto domaćeg prihoda, troškovi za zdravstvo po glavi stanovnika su znatno niži nego u dobro razvijenim zemljama, i zbog toga dostupnost ciljane terapije još nije na zadovoljavajućem nivou.

Ključne reči: ciljana terapija; biološki lekovi; troškovi; refundiranje; Srbija 